Katarzyna Caban-Piaskowska orcid.org/0000-0003-2400-2003

Wydział Sztuk Projektowych

Akademia Sztuk Pięknych im. Władysława Strzemińskiego w Łodzi

Łukasz Chmielewski (D) orcid.org/0000-0003-1653-9871

Wydział Sztuk Plastycznych

Akademia Sztuk Pięknych im. Władysława Strzemińskiego w Łodzi

\title{
KOMUNIKACJA WIZUALNA W NAUCE O ZARZĄDZANIU NA PRZYKŁADZIE POSTERU NAUKOWEGO
}

\section{Abstract \\ VISUAL COMMUNICATION IN MANAGEMENT SCIENCE BASED ON THE EXAMPLE OF SCIENTIFIC POSTER}

The article describes the essence of visual communication and the tools for its design, including the reason for addressing these issues in management sciences. The scientific poster is presented as an example of the use of visual communication presents. The results of research on critical analysis of the literature in the field of management and applied arts, including graphics and related sciences covering issues related to visual communication design, were presented. The research shows that in the literature on scientific posters there are publications which only describe the correct substantive structure, i.e. the content, and when it comes to the issues of visual communication (tools), they are very inaccurate and unreliable, or even misleading.

Keywords: visual communication, science poster, design of visual communication, design of scientific posters

\section{Wprowadzenie}

Problematyka projektowania komunikacji wizualnej w obszarze zarządzania mediami odgrywa coraz większą rolę (Kawka, 2015). Do prezentacji tego zagadnienia wybrano przykład posteru naukowego, ze względu na jego coraz większą 
popularność i prostotę. W ostatnich latach często na konferencjach naukowych są organizowane sesje posterowe. Poster naukowy w sposób prosty i przejrzysty ma przybliżyć oglądającemu tematykę publikacji, czyli może być świetnym przykładem, jak powinien wyglądać dobry komunikat wizualny. Często jednak tak się nie dzieje, przede wszystkim ze względu na liczne błędy projektowe, głównie graficzne, które pojawiają się w tych komunikatach naukowych.

Celem artykułu jest krytyczna analiza literatury przedmiotu z zakresu projektowania komunikacji wizualnej i sztuki użytkowej, w tym grafiki i nauk pokrewnych obejmujących zagadnienia związane $\mathrm{z}$ ich tworzeniem, a także nauki o zarządzaniu. Artykuł ma charakter teoretyczny, a studia literaturowe zostały wsparte wynikami obserwacji uczestniczącej jednego ze współautorów prowadzonej w okresie od 1994 do 2020 roku.

Autorzy tekstu skoncentrowali swoje badania na budowaniu wartości komunikatu wizualnego na przykładzie posterów naukowych. Ze względu na interdyscyplinarny charakter zarządzania mediami połączono wiedzę z zakresu percepcji i komunikacji wizualnej z wiedzą dotyczącą zarządzania w obszarze prezentacji naukowych.

\section{Komunikacja wizualna}

Prawidłowo zaprojektowana informacja jest podstawą wzajemnego zrozumienia (Fiske, 2003). Zaniedbywanie którejkolwiek płaszczyzny czy kanału komunikacji może doprowadzić do jej zaburzenia, co skutkuje opóźnieniem bądź zniekształceniem samej informacji. Analogicznie jak w przypadku komunikacji werbalnej, w której liczy się sposób artykulacji, tak w jej wizualnym odpowiedniku forma ma bezpośredni wpływ na treść komunikatu (Fiske, 2003; Griffin, 2006).

\subsection{Istota projektowania komunikacji wizualnej}

Celem każdej grafiki o charakterze informacyjnym jest takie przedstawienie danych, by zrozumienie ich było szybsze, łatwiejsze i - co za tym idzie - skuteczniejsze (Rendgen, Wiedemann, 2012). Wszystkie cechy wizualne takiego obrazu muszą być zatem podporządkowane skuteczności. Ważna jest tylko funkcja, jaką ma spełnić, czyli jednoznacznie przekazać informację (Wolny-Zmorzyński et al., 2013; Witek, 2014; Osiński, 2015; Cicha, 2017).

Przykładem tego, jak można zmanipulować komunikat, stosując odpowiednie narzędzia komunikacji wizualnej, są wyniki wyborów prezydenckich w Stanach Zjednoczonych z 2000 roku, kiedy to głosami wyborców Florydy wygrał George W. Bush. W tym stanie zostały wykorzystane karty wyborcze zaprojektowane w ten sposób, że część osób zakreśliła zamiast jednego - dwa nazwiska, oddając tym samym głos nieważny, lub - pomimo iż chciała zagłosować na przeciwnika Busha, 
Ala Gore’a - omyłkowo oddała głos na Pata Buchanana. Prawdopodobnie suma pomyłek zaważyła na zwycięstwie Busha. Pomimo protestów sąd uznał ważność wyborów i czterdziestym trzecim prezydentem Stanów Zjednoczonych został George W. Bush (Fessenden, Broder, 2001). Jest to przykład na potwierdzenie znaczenia i wpływu projektu graficznego na czytelność oraz jednoznaczność komunikatu.

\subsection{Fizjologia widzenia}

Umiejętność gromadzenia, przekazywania i analizowania informacji jest podstawą i czynnikiem sprawczym rozwoju cywilizacji. Punktem wyjścia w formowaniu się narzędzi międzyludzkiej komunikacji jest fizjologia człowieka. Badania dowodzą, że podstawowym zmysłem człowieka jest wzrok. Narząd ten ewoluował miliony lat, stale dostosowując się do warunków i potrzeb ludzi. Forma, jaką człowiek obecnie się posługuje, ukształtowała się na długo przed wynalezieniem pisma, a podstawowym czynnikiem kształtującym były warunki środowiskowe (Zalewski, 2006).

„Kiedy na siatkówkę pada obraz, neurony przesyłają o tym informację do mózgu za pomocą impulsów elektrochemicznych. Informacja dociera w ciągu 0,1 sek. do odpowiedniego obszaru kory mózgowej, gdzie jest interpretowana. Widać z tego, że widzenie jest raczej kwestią mózgu niż oczu" (Ackerman, 1994, s. 238). To mózg człowieka decyduje zatem o tym, co widzi. W związku z tym, że proces widzenia zachodzi niezwykle szybko, dzieje się to bez udziału świadomości. Miliony lat ewolucji wyposażyły człowieka w aparat „instynktownych” reakcji, które dzięki nauce zostały uporządkowane.

\subsection{Złudzenia wzrokowe}

Percepcja wzrokowa jest ściśle związana z fizjonomią i procesami zachodzącymi w mózgu człowieka. Niezwykle istotna - dla właściwego projektowania grafiki o charakterze informacyjnym - jest znajomość tych procesów i wynikających z nich implikacji. Jednym z najistotniejszych problemów percepcji wzrokowej są złudzenia wzrokowe, na powstawanie których człowiek nie ma świadomego wpływu. Mózg, wykorzystując stereoskopową budowę aparatu wzroku, tworzy symulację obrazu trójwymiarowego. Każdy obserwator, patrząc na przykład na fotografię, rozumie, że jest ona płaska, ale jednocześnie „widzi” obraz trójwymiarowy. Cała historia malarstwa europejskiego opiera się na tym złudzeniu. Do skutecznego symulowania przestrzeni trójwymiarowej skonstruowano nawet proste urządzenie optyczne (camera obscura), którego zadaniem było skuteczniejsze „przenoszenie" przestrzeni na płaszczyznę. Wykorzystanie wiedzy na temat właściwości wzroku legło również u podstaw wynalezienia filmu. Obraz odbierany jako ruchomy jest w rzeczywistości sekwencją wyświetlanych kolejno nieruchomych obrazów z tak dobraną szybkością (24 klatki/sek.), aby ludzki mózg zinterpretował zaistniałą 
projekcję jako ruch ciągły. Wynika to z częstotliwości, z jaką mózg może „odświeżać” obraz (Mijksenaar, 1997; Horn, 2000; Arnheim, 2012).

\section{Sposoby projektowania komunikacji wizualnej na podstawie posterów naukowych - studia literaturowe}

\subsection{Metoda badawcza}

Wybór pozycji literaturowych był podyktowany zróżnicowanym podejściem twórców do komunikacji wizualnej i jej projektowania na przykładzie posterów naukowych. Obejmował literaturę z okresu od 1994 do 2020 roku. Zbieranie danych $\mathrm{z}$ różnych obszarów naukowych było podyktowane tym, że problematyka projektowania komunikacji wizualnej w obszarze zarządzania mediami ma interdyscyplinarny charter - jest wykorzystywana w różnych naukach - tudzież chęcią obszernej analizy oraz lepszego zrozumienia samego zjawiska. W celu uzupełnienia wniosków z pogłębionej i wnikliwej analizy literatury skorzystano z danych z obserwacji uczestniczącej jednego ze współautorów, która dotyczyła posterów naukowych, co dało szanse uzyskania możliwie dokładnego i wielostronnego obrazu przypadków danego zjawiska. Badania były przeprowadzone w latach 1994-2020.

\subsection{Komunikacja wizualna w literaturze przedmiotu}

$\mathrm{Na}$ temat projektowania komunikatu graficznego powstało wiele opracowań. W ramach dziedzin związanych z zarządzaniem, które ma charakter interdyscyplinarny, jest wiele przykładów doskonale przeanalizowanych obszarów, które w znacznym stopniu komunikują obrazem (Rendgen, Wiedemann, 2012). Przykładem jest branding, który w wielu przedsiębiorstwach stał się strategią i ma wymierny wpływ na wyniki finansowe. Obecnie jego znaczenia, wagi i potencjału nikt nie kwestionuje (Wolny-Zmorzyński et al., 2013).

Na temat prezentacji danych również znaleźć można wiele cennych pozycji opisujących tę dziedzinę w sposób głęboki i wieloaspektowy (Rendgen, Wiedemann, 2012), które analitycznie ujmują omawianą problematykę. Jednak nie dotyczą one stricte projektowania graficznego w naukach o zarządzaniu i w związku $\mathrm{z}$ tym nie są one obszarem badań do tego opracowania.

\subsection{Komunikacja wizualna na przykładzie posterów naukowych}

W celu dokonania analizy, jak powinien wyglądać dobrze zaprojektowany komunikat wizualny, autorzy zdecydowali się na zgłębienie procesu projektowania posteru naukowego. Jest to dobry przykład stosowania komunikacji wizualnej ze względu na swoją prostotę i przejrzystość. Plakat naukowy, często nazywany posterem, 
jeśli jest prawidłowo skonstruowany, może być bardzo dobrą graficzną formą prezentacji wyników badań. Ta forma prezentacji naukowej powstała w drugiej połowie XX wieku. Zadaniem tego komunikatu jest zaprezentowanie treści badawczych - szczegółowo opisanych w referacie lub artykule - w sposób jak najbardziej atrakcyjny, żeby przyciągnąć uwagę uczestników sesji posterowej (plakatowej) (Weiner, 2003; Czachorowski, 2016; Plakat naukowy, 2016).

Istnieją opracowania wyjaśniające, jak należy przygotować właściwy poster. Opisują one jednak przede wszystkim prawidłową strukturę merytoryczną, zawartość poszczególnych i koniecznych elementów, czyli przede wszystkim treść. To bardzo ważny etap, bez którego grafik nie może rozpocząć pracy - jest to jednak faza redakcyjna, preprojektowa (Ignaciuk, 2015; Czachorowski, 2016; Plakat naukowy, 2016).

Publikacje dotyczące projektowania strony graficznej posterów naukowych mają nieprecyzyjny charakter. W jednej z nich można przeczytać, że doby poster „nie męczy oczu - ważna jest oprawa graficzna. (...) Ale ogólnie głowa do góry, jeżeli Twój plakat jest kiepski, to dołącz do niego cukierki, ciastka” (Ignaciuk, 2015). Materiał ten zamieszczony jest na domenie Uniwersytetu Jagiellońskiego (sic!). Zasadniczy problem polega na tym, że projekt graficzny nadal nie jest traktowany jako ważny element komunikacji wizualnej i przekazywania wiedzy naukowej.

Ponadto istnieją opracowania, z którymi autorzy artykułu się nie zgadzają. Barbara Krasińska pisze: „Kolorystyka błękitno-zielona daje wrażenie, że wygląd posteru staje się atrakcyjny, czysty i profesjonalny" (Krasińska, 2016, s. 6). Określenie atrakcyjny nie jest ani pojęciem projektowym, ani naukowym, a ponadto ma charakter subiektywny. Komunikat wizualny powinien być skuteczny, czyli przejrzysty i łatwy do zapamiętania. Autorka pisze także: „Podczas projektowania warto zweryfikować swój układ kolorystyczny z kołem barwnym, można mieć pewność, że trzy sąsiednie kolory będą się odpowiednio komponować. Warto również postawić na mały kontrast w całym projekcie (będą to kolory z przeciwnej strony koła barwnego)" (Krasińska, 2016, s. 5). Przytoczony fragment jest przykładem braku wiedzy projektowej i braku podstaw merytorycznych do projektowania komunikacji wizualnej. Po przeciwnej stronie koła barwnego są kolory o największym kontraście. W tej publikacji brak rzetelnej wiedzy naukowej, a autorka prezentuje jedynie subiektywny gust.

\subsection{Błędy w przygotowaniu komunikatów wizualnych}

Z obserwacji wynika, że źle przygotowany materiał wizualny prezentowany - jak w przypadku plakatów naukowych - podczas konferencji posterowej nie tylko nie ułatwia, ale także wręcz utrudnia i deprecjonuje prezentowane efekty. Przypadkowe wielkości poszczególnych elementów, chaotyczna kompozycja, niekonsekwentne obramowania wykresów, zbyt duża niezagospodarowana powierzchnia tła - wszystkie te czynniki tworzą „wrażenie” chaosu i braku profesjonalizmu. 
Przygotowanie i przeprowadzenie badania nie miało na pewno takiego charakteru, niemniej odbiorca pozostaje z takim „wrażeniem”.

Grafika projektowa, a w szczególności infografika, ma funkcję wspierającą treść. Niewłaściwe jej zastosowanie może jednak wypaczać treść i zmieniać jej sens (Smiciklas, 2012). W dziedzinie infografiki zauważalny jest ogromny postęp, w związku z tym nie można złej jakości materiału graficznego na konferencjach posterowych uzasadniać niskim budżetem czy niewielkim kręgiem odbiorców, którym „nie zależy” na formie, ponieważ oczekują samej treści. Z badań wynika, że zła grafika może wpłynąć nawet na wynik wyborów prezydenckich mocarstwa, niezależnie od tego, czy był to efekt zamierzony, czy nie.

\section{Zalecenia do projektowania komunikacji wizualnej - na przykładzie posteru naukowego}

Kwestia projektu graficznego jest niezwykle istotnym problemem w komunikacji wizualnej. Pierwszym, podstawowym czynnikiem jest właściwy dobór samego medium, przestrzeni, na której pojawi się informacja. Związane jest to bezpośrednio z samym odbiorcą oraz rodzajem komunikatu. W przypadku posterowych prezentacji naukowych taka sytuacja jest z góry zaplanowana, a odbiorcami są naukowcy - wąskie grono specjalistów znających prezentowaną problematykę. Takie warunki mogą zostać mylnie zinterpretowane - pozornie nie trzeba bowiem poświęcać zbyt dużo czasu na opracowanie formy graficznej dla osób, które znają problem - liczy się tylko treść. Taki sposób myślenia to błąd kardynalny - wzrok w początkowym etapie analizuje obrazy bez udziału ludzkiej świadomości. Niejasności mogą pojawić się zatem niezależnie od wiedzy i doświadczenia odbiorcy (Frith, 2011).

$Z$ badań wynika, że gdy jest ustalona treść, audytorium i miejsce prezentacji, należy zastanowić się nad następną podstawową kwestią, czyli wielkością fizyczną prezentacji i jej kompozycją czasoprzestrzenną. W przypadku posterów nie ma możliwości panowania nad tym, co obserwator widzi w danym momencie, każdy patrzy w dowolne miejsce i każdy w inne.

W artykule tym - ze względu na ograniczone miejsce i zbyt szeroki zakres problemowy - nie zostały umieszczone szczegółowe instrukcje projektowe, niemniej należy zwrócić uwagę na pewne podstawowe problemy, z którymi przyjdzie się zmierzyć projektantowi przy tworzeniu komunikatu wizualnego.

\subsection{Format}

Z badań wynika, że właściwe projektowanie zaczyna się od określenia formatu, na którym pojawi się komunikat. Płaszczyzna posiada pewne właściwości. Jej dobór uwarunkowany jest przede wszystkim czynnikami środowiskowymi (otoczeniem), 
w jakim ma się pojawić lub wytycznymi podanymi przez organizatorów - w badanym przypadku będzie to konferencja.

Projektowanie posteru naukowego ma na celu zwrócenie uwagi oglądającego. Płaszczyzna plakatu posiada dwie podstawowe orientacje: pionową i poziomą (kwadrat zdarza się niezwykle rzadko), które same w sobie są odpowiednio: dynamiczne lub statyczne. Inne będą zatem relacje wynikające z podziałów (osiami symetrii i przekątnymi) poszczególnych obszarów płaszczyzny. Z wieloletnich badań wynika, że książki przeznaczone do składu tekstu ciągłego zakomponowane są w układzie pionowym (autorzy nie mają tu na myśli niektórych katalogów reklamowych), a billboardy i telewizory mają układ horyzontalny. Ponadto ma to związek z innym ważnym aspektem dotyczącym samego formatu, czyli wielkością fizyczną. Ze względu na konstrukcję aparatu wzroku człowieka najlepiej czyta się tekst ciągły, który mieści się w przedziale około 9-12 punktów w systemie Didota, złożony pismem szeryfowym dwuelementowym (Felici, 2009).

\subsection{Kompozycja}

Z obserwacji wynika, że kompozycja poszczególnych elementów składowych tworzy podstawową strukturę, tkankę komunikatu wizualnego. Człowiek rozróżnia podstawowe typy kompozycji: zamkniętą, otwartą, rytmiczną, dynamiczną, statyczną każdy typ niesie ze sobą pewne cechy, które mogą wzmocnić bądź osłabić czytelność każdego projektu, a dobór tej właściwej, odpowiadającej charakterystyce prezentacji jest kolejnym ważnym krokiem ku czytelności przekazu (Arnheim, 2012).

Kompozycje wieloelementowe (tabele, kolumny tekstowe, ikonki, symbole) wymagają narzucenia porządku merytorycznego, jednak forma graficzna musi ów porządek podkreślać w sposób umożliwiający zrozumienie jego istoty jeszcze przed analizą merytoryczną; informacje merytoryczne mają objaśniać infografikę, nigdy odwrotnie. Dobrym tego przykładem są mapy, które są rozumiane bez komentarza - legenda jest potrzebna, kiedy oglądający chce wiedzę uszczegółowić (Racine, 2002).

\subsection{Wykorzystanie geometrii w projektowaniu}

Dość częstym błędem w komponowaniu elementów na płaszczyźnie jest nadmierna chęć sprowadzenia wszystkich elementów do ram narzuconych przez geometrię. Jednak nieświadome i niezależne od człowieka deformacje optyczne związane z procesem percepcji często biorą górę nad poprawnością geometryczną. Ludzki organizm i tym samym zmysł wzroku dostosował się do funkcjonowania na Ziemi, która poddawana jest nieustającej sile grawitacji oraz światłu słonecznemu. W związku z tym za naturalne uznawane jest, że każdy przedmiot posiada ciężar oraz jest oświetlony od góry (Traufetter, 2009, s. 116). Bazuje na tym między innymi pojęcie środka optycznego charakteryzującego się tym, że obiekt umiejscowiony 
na idealnym środku geometrycznym płaszczyzny jest postrzegany jako umieszczony „zbyt nisko” (zob. rysunek 1). Z kolei gradientom wypełniającym płaskie koła nadawany jest kształt wypukłych lub wklęsłych kul, co symuluje tym samym padanie promieni słonecznych, które zawsze padają z góry (zob. rysunek 1).

\section{Rysunek 1. Złudzenia optyczne z użyciem symetrii i gradientów}

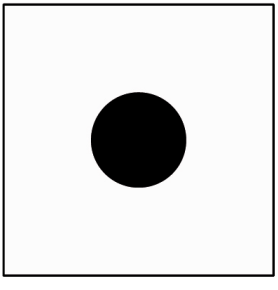

środek geometryczny

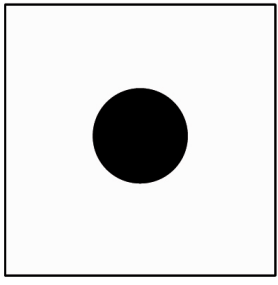

środek optyczny koła wypukłe

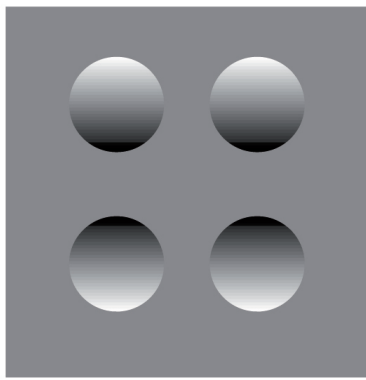

te same koła obrócone o $180^{\circ}$

Źródło: opracował Łukasz Chmielewski na podstawie Traufetter, 2009.

\subsection{Kolor w projektowaniu}

Kolejnym ważnym aspektem, który musi zostać uwzględniony w procesie projektowania każdego komunikatu graficznego, w tym także prezentacji posterowej, jest kolor. Niestety często wybory w tym zakresie nie wynikają z wiedzy i uwarunkowań procesu percepcji, a są one wynikiem gustu bądź stereotypowych przyzwyczajeń kulturowych, takich jak przekonanie, że różowy jest dla dziewczynek, a niebieski dla chłopców. Kolor jest wtórny w stosunku do kształtu - człowiek widzi kształt, potem dopiero kolor. Znaczenie koloru jest jednak trudne do przecenienia w komunikacji wizualnej. Bardzo ważny jest przede wszystkim nie tyle dobór koloru wiodącego (tonacji), ile całej gamy kolorystycznej - kolory niezależnie od woli człowieka zmieniają się zależnie od swego sąsiedztwa (zob. rysunek 2) (Itten, 2015). Oczywiście nie zmieniają się kolory same w sobie, ale ich mózgowa interpretacja (Tatarska, 2013, s. 24-59). 
Rysunek 2. Złudzenie optyczne z użyciem koloru i waloru

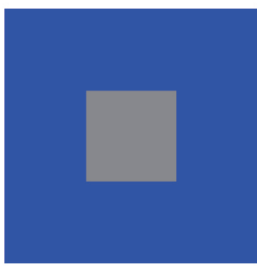

szary jest ten sam w obu przypadkach

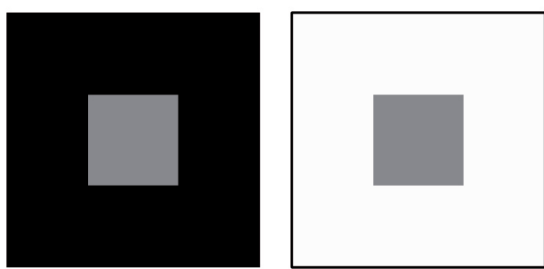

szary jest ten sam w obu przypadkach

Źródło: opracował Łukasz Chmielewski na podstawie Itten, 2015.

\section{Wnioski i podsumowanie}

Z przeprowadzonych badań literaturowych wynika, że problematyka projektowania komunikacji wizualnej w obszarze zarządzania mediami jest bardzo istotnym i złożonym problemem. W literaturze przedmiotu dotyczącej projektowania komunikacji wizualnej na przykładzie posterów naukowych pojawiają się publikacje, które jedynie opisują prawidłową strukturę merytoryczną, czyli treść, problematykę komunikacji wizualnej traktują zaś w sposób powierzchowny i nieadekwatnie swobodny. Autorzy zdecydowali się na krytyczną analizę literatury przedmiotu $\mathrm{z}$ zakresu zarządzania, grafiki i nauk pokrewnych, obejmujących zagadnienia związane $\mathrm{z}$ posterami naukowymi i ich projektowaniem. Ponadto $\mathrm{z}$ analizy literatury przedmiotu dotyczącej znaczenia komunikacji wizualnej wynika, że o ile istnieje bardzo dużo publikacji dotyczących w znacznym stopniu komunikacji obrazem, takich jak branding, o tyle dorobek z zakresu komunikacji wizualnej stosowanej w projektowaniu posterów naukowych jest niewielki, a poziom jego bardzo niski, obarczony licznymi błędami merytorycznymi.

Ważna jest świadomość, że percepcja wzrokowa nie jest tożsama z estetyką i przynależnymi jej kategoriami, której kryteria oceny mieszczą się w granicach gustu i wszystko wyjaśniającego słowa „ładne”, a są wynikiem naukowych badań z wielu obszarów - neurobiologii, fizyki, psychologii i - wreszcie - wsparte doświadczeniem wywodzącym się ze sztuki użytkowej (w szczególności grafiki). Wiedza z zakresu percepcji wzrokowej jest wykorzystywana z ogromnym sukcesem od dziesięcioleci w większości obszarów związanych ze zmysłem wzroku: w reklamie, komunikacji przestrzennej, brandingu, filmie, fotografii, dziennikarstwie i wielu innych dziedzinach pokrewnych (Terelak, 2004, s. 293-311; Tatarska, 2013, s. 24-59).

Ogromny trud wkładany w badania naukowe nie powinien być pomniejszany przez formę komunikacji, która w przypadku nieumiejętnego stosowania może zaszkodzić efektom samej pracy. 
Artykuł ten jest przyczynkiem do badań w obszarze komunikacji wizualnej. Planowane są badania obejmujące analizę i porównanie posterów naukowych oraz e-posterów, typu konferencji, na jakich są publikowane, analizę tego, jakich błędów unikać przy ich tworzeniu, jakie są najlepsze wzorce, a także - czy tego typu wytyczne są publikowane przez uczelnie zagraniczne dla swoich studentów i pracowników.

Ponadto planowane są publikacje obejmujące praktyczne wytyczne dla autorów, jak przygotować dobry komunikat, w tym poster naukowy.

Celem artykułu nie jest deprecjonowanie czy krytykowanie - jest nim jedynie wskazanie pewnego obszaru komunikacji, który - zdaniem autorów - powinien stać się przedmiotem gruntownej analizy w celu jego ulepszenia.

\section{Bibliografia}

Ackerman D. (1994). Historia naturalna zmysłów. Warszawa: Książka i Wiedza.

Arnheim R. (2012). Myślenie wzrokowe. Gdańsk: Słowo/Obraz Terytoria.

Cicha K. (2017). Komunikacja wizualna - humanistyczne oblicze informatyki? „Zeszyty Naukowe Uniwersytetu Ekonomicznego w Katowicach", nr 317, s. 42-53.

Czachorowski S. (2016). Plakat naukowy (poster). Pobrane z: http://www.uwm.edu.pl/czachor/ dyda/poster.htm (dostęp: 15.07.2018).

Felici J. (2009). Kompletny przewodnik po typografi. Zasady doskonałego składania tekstu. Gdańsk: Słowo/Obraz Terytoria.

Fessenden F., Broder J.M. (2001). EXAMINING THE VOTE: THE OVERVIEW; Study of Disputed Florida Ballots Finds Justices Did Not Cast the Deciding Vote. „The New York Times”, $12^{\text {th }}$ November, s. 1.

Fiske J. (2003). Wprowadzenie do badań nad komunikowaniem. Wrocław: Wydawnictwo Astrum.

Frith Ch. (2011). Od mózgu do umysłu. Warszawa: Wydawnictwa Uniwersytetu Warszawskiego.

Griffin R.W. (2006). Podstawy zarządzania organizacjami. Warszawa: Polskie Wydawnictwo Ekonomiczne.

Horn R.E. (2000). Information Design: Emergence of a New Profession. W: R. Jacobson (ed.), Information Design (s. 15-33). Cambridge: The MIT Press.

Ignaciuk W. (2015). Jak przygotować poster naukowy. Krótki poradnik. Pobrane z: http://skryba. inib.uj.edu.pl/ nahotko/Zrodla-dokt/postery.pdf. (dostęp: 15.07.2018).

Itten J. (2015). Sztuka barwy. Kraków: d2d.

Kawka M. (2015). Komunikowanie wizualne a nauka o mediach - wspótczesność i perspektywy. „Media i Społeczeństwo”, nr 5, s. 13-21.

Krasińska B. (2016). Plakat naukowy (poster) jako narzędzie promowania bibliotecznych konferencji oraz wspótczesna forma wizualizacji komunikatu naukowego. „Elektroniczne Czasopismo Biblioteki Głównej Uniwersytetu Pedagogicznego im. KEN w Krakowie”, nr 9, s. $1-12$.

Mijksenaar P. (1997). Visual Function: An Introduction to Information Design. Rotterdam: 010 Publishers.

Osiński G. (2015). Kognitywne aspekty komunikacji wizualnej. Toruń: Wydawnictwo WSKSiM. 
Plakat naukowy (2016). Pobrane z: https://pl.m.wikipedia.org/wiki/Plakat_naukowy (dostęp: 15.07.2018).

Racine N. (2002). Visual Communication: Understanding Maps, Charts, Diagrams, and Schematics. New York: Learning Express.

Rendgen S., Wiedemann J. (eds.) (2012). Information Graphics. Cologne: Taschen.

Smiciklas M. (2012). The Power of Infographics: Using Pictures to Communicate and Connect with Your Audiences. Que Publishing.

Tatarska J. (2013). Rola koloru w reklamie prasowej. W: A. Wiśniewska, A. Frontczak (red.), Reklama wizualna (s. 24-59). Warszawa: Wyższa Szkoła Promocji.

Terelak J.F. (2004). Psychologiczne aspekty reklamy wizualnej. „Studia Psychologica”, nr 5, s. $293-311$.

Traufetter G. (2009). Intuicja, czyli mądrość uczuć. Warszawa: Wydawnictwo W.A.B.

Van Dijk J.A. (2005). The Network Society: Social Aspects of New Media. London: Sage Publications.

Weiner J. (2003). Technika pisana i prezentowania przyrodniczych prac naukowych - przewodnik praktyczny. Warszawa: Wydawnictwo Naukowe PWN.

Witek E. (2014). Komunikacja wizualna. Nowoczesne narzędzia. Wrocław: Wydawnictwo Astrum.

Wolny-Zmorzyński K., Furman W., Snopek J., Groń K. (2013). Komunikacja wizualna w prasie $i w$ mediach elektronicznych. Warszawa: Wydawnictwo Poltext.

Zalewski P. (2006). Eyetracking w badaniach użyteczności. Pobrane z: https://www.internetstandard.pl/news/Eyetracking-w-badaniach-uzytecznosci,91102.html (dostęp: 7.05.2020). 